\title{
Balinese Migrants in Indonesia : Political Of Ethnic Identity in Multicultural Society
}

\author{
Zainal Arifin ${ }^{1}$, Maskota Delfi ${ }^{2}$, Sidarta Pujiraharjo ${ }^{3}$ \\ $\left\{\right.$ arifinzed@soc.unand.ac.id $\left.{ }^{1}\right\}$ \\ Department of Anthropology, Faculty of Social and Political Sciences, Andalas University, Padang, \\ West Sumatra, Indonesia
}

\begin{abstract}
Lampung is a multicultural region where various ethnic groups in Indonesia can be found and settle in this region, and among them is The Balinese. The Balinese community migrated to Lampung through the transmigration process in 1963 due to the eruption of Mount Agung. One of the Bali migrant communities lives in Bali Sadhar village in Banjit sub-district of Way Kanan Regency of Lampung Province. This Balinese (Bali Sadhar) community in Lampung lives side by side with other communities that have very different cultural values, such as Lampung, Semende, Ogan, Javanese, and Sundanese. Balinese communities have a strong Hindu cultural identity, while the surrounding communities have a strong Islamic identity combined with its rituals. The strength of this Balinese Hindu identity can cause cause them to often conflict with other ethnic groups around, but the Balinese community (Bali Sadhar) in Way Kanan can actually live in harmony with the surrounding communities. This article explains how identity politics is carried out by the Bali Sadhar community in Lampung. The success of identity politics of the Bali Sadhar community is done by redefining the cultural values (Hinduism) they have in accordance with their environmental conditions. As the result, these people are still able to realize their cultural identity and also able to coexist in harmony with the other communities.
\end{abstract}

Keywords: multicultural community; identity politics; redefinition and reconstruction; cultural conformity; Bali; Lampung.

\section{INTRODUCTION}

In 1963, Mount Agung in Karangasem Regency Bali Province erupted. This eruption damaged various regions in Karangasem Regency and some areas in the surrounding districts so that the residents had to be evacuated and moved. One form of handling the Mount Agung eruption disaster was through a program of transmigrating the people to various regions in Indonesia ${ }^{1}$, including Banjit sub-district, Way Kanan Regency, Lampung Province. The Balinese people transmigrated to the Banjit region came from various regions in Bali such as Karang Asem, Tabanan, Bangli, Singaraja, Kelungkung, and Nusa Penida ${ }^{2}$. In this transmigration area (Banjit),

\footnotetext{
${ }^{1}$ The efforts to deal with the impact of the Mount Agung eruption were done by the government through a program known as KOGA (Gunung Agung Operational Command). ${ }^{2}$ The Bali migrant community in Banjit comes from various regions in Bali such as Karangasem (dominates the North Bali Sadhar), Tabanan, Bangli and Singaraja (dominates the Central Bali Sadhar), Kelungkung and Nusa Penida (dominates the South Bali Sadhar).
} 
they built a settlement which is later called as Bali Sadhar meaning the Balinese people who were aware and wanted to move to another area (transmigrating). Today, administratively the Bali Sadhar community is concentrated in 3 villages, namely: (1) North Bali Sadhar Village, (2) Central Bali Sadhar Village, and (3) South Bali Sadhar Village.

At the time of transmigration in 1963, several other ethnic groups (most of them were farmers), such as Lampung, Semende, Ogan, Javanese, Sundanese, and Banten, had settled in this Banjit area. The arrival of the Balinese community in the Banjit area initially raised concerns for most of the local communities around it. One of these concerns is because Bali is a community that holds quite tightly to its Hindu values, while the local communities around it (especially Lampung, Semende, and Ogan) are devout Muslim adherents ${ }^{3}$. This concern was not only expressed by the local community in the form of a stereotype that the Bali Sadhar worshipping idols and consuming pigs but also giving rise to prejudice that caused the Bali Sadhar community tended to be isolated in their social interactions. Cases like this are not only experienced by the Balinese community (Bali Sadhar) but also experienced by many migrant communities in different cultures in Lampung (Romli and Ayu Maulia, 2011).

This condition had not only made the Bali Sadhar community feel alienated in new society but also felt "frustrated" thinking whether they could survive in an effort of improving the economy of their lives in this new area. At first, this condition was tackled by always communicating with the residents of Bali sanctuary and the Balinese community that had existed in several regions in Lampung. In later developments, several community leaders of Bali Sadhar also finally built infrastructure in the form of buses used as transportation for the Bali Sadhar community to go to various regions in Lampung and even then this transportation route eventually reached Bali. This method is effective enough to break an alienation in the new areas, as well as to build the confidence that they "must" become Bali-Lampung. ${ }^{4}$

Culturally, it is not easy for the Bali Sadhar people to establish themselves as Bali-Lampung. The cultural and religious differences they have with the local communities around them are highly potential to create conflicts in their communities. However, since their existence in the Banjit area, the conflict has not actually broken into SARA (ethnics, religions, and races) conflicts in their communities. This success is not only due to the awareness and support of all the surrounding ethnic communities in placing themselves as a multicultural society. However, it is also due to the ability of the Bali Sadhar people to display their identity that is in harmony with the identity of the local communities around them.

Based on this thought, it is interesting to understand how the identity politics is built in the Bali Sadhar community so that they are still able to maintain their identity and able to harmonize it with the local communities around them. This article attempts to provide an overview of the identity politics carried out by the Bali Sadhar community in the multicultural society in Lampung. It is not only essential to give us an understanding of the cultural strategies of migrant communities in new areas but also to spark an idea of how identity politics is able to harmonize patterns of relationships and social interactions in multicultural communities.

\footnotetext{
${ }^{3}$ The view of the local communities that the Balinese community is different from "them" is still felt by most Balinese in Bali Sadhar until now.

${ }^{4}$ The expression of the Bali Sadhar community to become Bali-Lampung was later popularized by tour guide with video entitled "the little Bali in Lampung".
} 


\section{Political of Ethnic Identity and Multiculturalism}

Multiculturalism is a concept that is frequently used by experts to emphasize the view of cultural diversity in a particular area of society. This diversity will eventually lead to distinctive patterns of interaction between communities and ethnicities with different cultures (Syaifuddin, 2006). The term 'multiculturalism' is also often interrelated with the concept of pluralism which is interpreted as the recognition and treatment of a community towards other communities because of the cultural differences. Pluralism refers to the state of society which consists of various ethnic groups, religions, origins and cultural backgrounds, without seeing the interaction between them (Tanudirjo, 2011). It means that the concept of pluralism emphasizes more on aspects of understanding or perspective that "we are different from them".

Unlike the concept of multiculturalism which emphasizes more on the ideological aspects of nationality and state (citizenship) ${ }^{5}$, as an ideology, multiculturalism must be fought for because it is the basis for the establishment of democracy, equality, human rights, and the welfare of the lives of the people (Suparlan, 2002). It is because the concept of multiculturalism was born from the belief that every citizen has the same position in his society so that every citizen has the right to maintain his identity, to be proud of his origins and ancestors, and to have the sense of belonging of himself and his group (Tanudirjo, 2011) Therefore, in the context of harmonization, the concept of multiculturalism finally emphasizes more on the political aspect in the form of policies towards the protection of diversity (Setyaningrum, 2003; Wasino, 2013). The political dimension of multiculturalism eventually leads to thinking of creating harmony, tolerance, mutual respect for differences and the rights of each culture that constitutes a nation.

In addition to the political aspect, multiculturalism also contains aspects of culture, where awareness of diversity is understood as the result of the social construction that is built in the social relations between ethnic communities in terms of the concepts of equality and inequality of identity (Setyaningrum, 2003). This shows that the understanding of multiculturalism must also be realized that it also contains the destructive and confrontational concepts. It creates conflicts between ethnicities, religions, and groups, as well as creates certain stereotypes and prejudices about certain cultural groups, which are described through myths, jokes, and certain stories (folklore). The problem is that the emphasis on the concept of multiculturalism as a political and cultural aspect --- both in the context of harmony and destruction --- tends to be understood in an external context, which is as a result of social relations between different actors and communities interacting within it. It is rare for multiculturalism to be understood in an internal context or as a product that exists and is embedded in the community of the cultural actors themselves.

The understanding of multiculturalism in an external context assumes that harmony and conflict occuring between communities are seen more as a result of crossing patterns of the relationships

\footnotetext{
${ }^{5}$ Here multiculturalism should be distinguished from the term multicultural. The term 'multicultural' is interpreted as a diversity of ethnic cultures in a region, while multiculturalism is defined as the treatment of a- person or group of people towards different cultural owners so that it creates harmony or conflict (see Suparlan, 2002; Tanudirjo, 2011).
} 
that are built in an area, where various communities live and interact. ${ }^{6}$ Putting the viewpoint of multiculturalism in this external context finally produces two opposing positions of thought. First, the idea that every community in a multicultural region needs to establish a pattern of relationships for the sake of building a unity (one culture). Secondly, the idea that every community in a multicultural region needs to respect each other's existence (many cultures) (Miller, 1995). The idea of the importance of unity (one culture) derives from the assumption that cultural differences have the potential to rise conflicts and divisions so that differences between cultures must be minimized so it produces a shared identity. Meanwhile, the idea of diversity (many cultures) derives from the assumption that every culture has its own entity and identity that cannot be equated with other entities and community cultures around it. The importance of building a unity in the context of this diversity will eventually lead to the action of the need for consensus, develop an attitude of harmony and solidarity, and build cross-ethnic affiliations among ethnics so that it is expected to suppress group domination and minimize the potential conflict. This action surely cannot be awakened itself, because there is a tendency that every cultural owner will still show and build his own identity. This condition will ultimately make efforts to harmonize and resolve inter-ethnic problems, requiring state intervention.

There are two problems when multiculturalism is placed in this external context. Firstly, multiculturalism is often understood in its relation to globalization. It means that globalization is often regarded as the cause of changes in the cultural identity of each ethnicity so that the "noble" values of harmony built in the culture of each ethnicity experience degradation and destruction (Parekh, 2008). Secondly, multiculturalism often ignores that every ethnic community actually has cultural values related to harmonization and disharmony (Suparlan, 2002). It means that internally each ethnic culture contains values in order to always harmonize the people with the surrounding communities and environments, as well as to always fight and engage with destructive attitudes. Based on this thought, understanding multiculturalism in the internal context within the community of the culture owner finally becomes important. This is based on the assumption that every community tends to always carry out a process of conformity in the context of its interaction with the environment at hand (Spradley, 1987). This means that there is always a value of adjustment culture (cultural conformity) in every community as an effort to defend themselves from extinction and destruction of their culture and community. The nature of compromise (conformity) is not only done in the form of reconciliation and consensus with the surrounding social environments but can also be done in the form of destructive resistance. This shows that each cultural group actually has a reservoir plasticity strategy that will be used by each group in dealing with their lives and survival (Spradley, 1987).

The conformity process is carried out by reproducing the identity and cultural values they have in accordance with the needs of the environment being faced. The success of the actors and groups in reproducing this identity cannot be separated from how they redefine and reconstruct the identity to win the fight (Arifin, 2018a; 2017). Here the concept of ethnic identity politics has finally become relevant in understanding multicultural issues as an internal concept of the culture actors of the community. According to Nicholson (2008), identity politics can be understood as a typical political movement carried out by communities in an area that is different

\footnotetext{
${ }^{6}$ This is for example reflected in the writings that try to describe why consensus occurs in the form of inter- ethnic harmony, tolerance and harmony in a multicultural region (see for example Firusy, 2015; Mudana, 2012; Haryanto, 2012; Kukathas, 1993).
} 
from other surrounding communities, where the differentiating identity can be in the form of tradition (culture), religion (belief), language, gender, economy or politics (Abdillah, 2014). Identity politics appears as a form of "self-adjustment" of a community towards the environmental conditions. Identity politics is raised as a form of communal awareness of their potential, and maximizing it in the form of a struggle to overcome various problems. Through this identity politics, each community will feel mutual solidarity in actualizing their existence. ${ }^{7}$

One form of the communal identities is a cultural identity that is usually ethnically based. This cultural identity is relatively strong to bring up and bind the solidarity of its members so that they tend to be effectively politicized as a political movement (Tarakanita, 2013). Referring to this thought, the ethnic identity politics meant here is the political movement carried out by ethnic communities in overcoming various problems faced in their lives (Arifin, 2012; 2013). As a movement, ethnic identity politics tends to be used and manifested in the efforts of organizing shared identities in order to win power over communities and other ethnic groups. As an identity, the culture is unique and only possessed by the ethnic group, so the organization is relatively more effective in fighting for common interests. Organizing ethnic identity is done by redefining and reconstructing the cultural values to be in accordance with the interests and values that are fought for. It means that the ethnic identity politics is not based on old cultural values, but uses cultural values that have been constructed by the owners of these cultures (Arifin, 2018b).

Ethnic identity politics is not only directed by ethnic communities to negotiate their sociocultural rights that are considered marginalized (West-Newman, 2004; Sjaf, 2014) but also aimed at affirming the existence of their cultural differences with the cultures of other communities around it (Hopkins, 2007). That is, ethnic identity politics is more as an effort to lead to different inter-cultural equality (principle of equality), not as an effort to seek a principle of similarity. This view is important because every culture will always strive to show and strengthen its identity, and try to ask for the legitimacy of their existence in other cultural groups around it (Parekh, 2001). The efforts to strengthen and ask for legitimacy do not only create harmony but also bring the consequences of conflicts, dominations, confrontations and destructions (May, 1999; Hintjens, 2001; O'Neill, 2003).

Through this view, the ethnic identity politics will then produce a conception called by Archer $(1985 ; 1982)$ as logical coherence and/or in the form of causal consensus. In this context, the logical coherence is seen as an internal fit between various cultural elements that influence it. Meanwhile, the causal consensus is the level of social uniformity produced due to the mutual consensus between social groups regarding the components that influence it. Archer's view of this logical coherence and causal consensus - as outlined in his morphogenesis theory - derives from the idea that every individual and social group has the ability to create a contradictory relationship (disharmony) while creating an orderly relationship (harmony). Therefore, the diversity of conceptions, ideas, and behaviours that develop in every cultural actor in a cultural

\footnotetext{
${ }^{7}$ In the study of political science, identity politics strongly distinguishes between political identity and politics of identity. Political identity is a construction that determines the position of the subject's interests in the bond of a political community. While political of identity refers to the political mechanism of organizing identities (both political identity and social identity) as political sources and means (Haboddin, 2012).
} 
community has "enforced" every member to "redefine" the cultural values possessed to be adapted to other cultural values, or vice versa (Archer, 1982).

\section{Political of Ethnic Identity : The Bali Migrant Case in Lampung}

Lampung Province is one of the provinces in Indonesia whose population consists of various ethnic groups. According to BPS records (2010), Lampung province has 7,608,405 individuals that are spread into various ethnic groups such as Lampung (13.51\%) as local residents, and immigrant ethnic groups such as Java (63.84\%), Sundanese $(9.58 \%)$, Ogan and Semende (5.78\%), Banten $(2.27 \%)$, Balinese (1.38\%), Minangkabau (0.92\%), Bataknese $(0.63 \%)$, Chinese $(0.53 \%)$, and Buginese $(0.28)$, and other ethnic groups in Indonesia. The composition of the population of Lampung Province, which is very multicultural, is more due to the fact that until the end of the Dutch colonialization, Lampung was considered a "no man's land" area (Kompas, 16 September 1996). It was only on July 21, 1939, ethnic Lampung began to impose communal (clan) land ownership based on the clan Reglement, No. 539 / IGOB S.1938 No. 490 (Hadikusuma, 1990).

Not only the multicultural condition of Lampung gave birth to cultural diversity and the process of cultures mixing of various ethnicities but also is vulnerable to conflicts between ethnics. ${ }^{8}$ One area that reflects the multicultural community in Lampung Province can be found in several districts in Way Kanan Regency, one of which is in the Banjit sub-district. Initially, Banjit was one of the areas belonging to the Lampung ethnic which was used as a farming area for the surrounding migrant communities, which generally came from Semende and Ogan ethnic groups from South Sumatra. In later developments, other ethnic groups such as Javanese, Sundanese, Bantenese, and Balinese finally arrived. This diversity in the Banjit region is not only shown by its ethnic diversity but also its religious diversity, namely Islam, Christianity, and Hinduism. There is a tendency for each ethnic group to gather in its own group and inhabit a separate area so that each ethnic group still carries on its own cultural identity, and always tries to strengthen and ask for recognition of their identity. Even so, until now the people can still live side by side peacefully.

Banjit Subdistrict was formed in 1972, where previously it was one of the villages in Kasui subdistrict. One of the ethnic communities inhabiting the Banjit area is the Balinese community which administratively inhabits 3 villages from 20 existing villages (BPS, 2017). The existence of the Balinese ethnic community in Lampung began from the transmigration which was carried out in 1963 due to the eruption of the Mount Agung, and one of the transmigration areas was in the Banis Banjit District. In the Banjit transmigration area, they were concentrated into a settlement which they later named Bali Sadhar which means the Balinese community who was aware and wanted to move to another area (transmigrating). ${ }^{9}$ Although the Bali Sadhar

${ }^{8}$ The study regarding the process of culture-mixing in Lampung society, see for example Yanti (2014); Afero (2013). Meanwhile, the discussion about conflicts that occur can be seen, for instance, from the study by Zulfa (2014); Romli (2014); Utami (2014); Karomani (2011).

${ }^{9}$ Now, the Bali Sadhar community is concentrated into 3 villages, namely: (1) Bali Sadhar Utara Village, (2) Bali Sadhar Tengah Village, and (3) Bali Sadhar Selatan Village. 
community comes from various regions such as Karang Asem, Tabanan, Bangli, Singaraja, Kelungkung and Nusa Penida, they have a common awareness as Balinese people.

One of the ethnicities of Bali Sadhar can be seen from the religion he or she adheres to, namely Hinduism. This religion has become a distinctive identity as Hinduism in the Balinese community is understood not only as a religion, but more as a custom (culture) that must be applied in life. As a religious teaching, Hinduism is positioned more as the spiritual values that surround people's lives in relation to God. While as a custom (culture), Hinduism is positioned as values that guide its community in daily life. This placement of Hinduism as a custom (culture) in society later brought up the term "Balinese Hindu" which means that the Hindu teachings applied by the Balinese community have a philosophy that is different from Hinduism in other areas, including in their home region in India.

To Bali Sadhar people, this Hinduism is understood as a teaching that contains a philosophy of balance in carrying out life (tri hata karana). The philosophy of the balance of life is applied in the form of the relationship patterns between humans and their God; between humans and their environment; and between humans and other humans. The pattern of balance between man and his God is applied in the form of always believing that there would be Brahmins, Vishnu, and Shiva (tri murti) who control human life in the world. Meanwhile, the balance between humans and the environment is applied in the form of always maintaining the balance of the environment by utilizing it in accordance with the designation. Furthermore, the balance of patterns of human relations is applied in the form of mutual respect to each other. The awareness of the philosophy of balance originating from Hindu teachings is then greatly influencing how the Bali Sadhar community lives their lives.

Bali Sadhar Community realizes that the philosophy of Hindu teachings about the balance will certainly have different applications according to space and time. That is, when the Hindu teachings are applied in Bali, the application will be different from what it is applied in Bali Sadhar, and it is also very possible to be different when applied in other areas in Lampung. The socio-cultural conditions of the surrounding community, environment, economic and political conditions greatly influence how the philosophical values in the Hindu teachings will be applied. This, for example, is reflected in the social structure of the community which is largely from the Sudra caste, ideally it is not possible to appoint a religious leader (from the Brahmin caste) as it was done in Bali. However, the existence of religious leaders is very much needed in the context of the pattern of human relations with their God.

The pattern of redefining and reconstructing a culture in accordance with the conditions of the surrounding environment is also reflected in the ceremonies carried out and the procedures for their implementation, which are highly adapted to economic conditions, the availability of natural resources and the socio-cultural conditions of Bali Sadhar. Every ceremony carried out will require a lot of money, so not all families will be able to carry it out. In cremation ceremony (ngaben) for example, every family in Bali Sadhar will relatively spend around IDR 100 million. Most of these costs are used to purchase and manufacture objects and ceremonial offerings, even some of which must be imported directly from Bali such as sandalwood, Balinese silk cloth and Uang Kepeng, due to the absence of these ceremonial objects in the Lampung area. The placement of each ceremony as a sacred activity has made a situation when not all ceremonial objects can be used, although the ceremonial objects are available and found in the Lampung region. This can be seen from Balinese silk fabrics, for example. Although the silk fabrics with 
motifs requested are available in Lampung, the silk cloth must be then ordered from Bali considering the sacred values are different.

Likewise, the socio-cultural conditions of the Bali Sadhar community and the surrounding communities also make the procedures for carrying out ceremonies experience redistribution and reconstruction. The Bali Sadhar community comes from various regions of Bali island, which are generally grouped in the Bali Aga and Bali Majapahit traditions. Although the Bali Sadhar community originating from these two regions of this tradition adheres to the same religious teachings (Hinduism), not all of them actually have cultural similarities related to the tradition of life. Therefore, the Bali Sadhar community realizes that not all Bali Aga and Bali Majapahit traditions must be done in their communities. Moreover, the socio-cultural conditions of the community around Bali Sadhar, which is mostly Muslim, also influence the redefinition and reconstruction of ceremonies and the way they live. One of the ceremonies which the Bali Sadhar community considers important is a joint eating ceremony as a sign of gratitude and bonding together (mengibung). The sacred value of the 'mengibung' ceremony is in a sense of togetherness among members and participants (sela), which is shown by the same way of eating in the 'dulang' or trays with members of about 6 to 8 people. Ideally, mengibung is not only aimed at the Balinese community but also aimed at non-Balinese communities. However, as part of the community around Bali Sadhar is Muslim (Islam), mengibung tends to only be done by a small number of families in the Bali Shadar community, even starting rarely as a joint activity in the community. ${ }^{10}$

The process of redefining and reconstructing the procedures and implementation of the ceremonies in Bali Sadhar makes only important ceremonies carried out by the Bali Sadhar Hindu community. These important ceremonies are more in terms of the ceremonies that are directly related to their lives on Bali Sadhar, such as ceremonies of purifying the heart and mind (melasti), ceremonies of gratitude and asking for salvation (tumpek), corpse burning ceremonies (ngaben), and in addition to ceremonies in Seclusion Day. Meanwhile, other ceremonies tend to be only as a tradition in life, and today it even starts to be rarely done. For instance, the ceremony of sacrifices as the evidence of sincere devotion (ngurek), the provisioning ceremony and delivering spirits to the nirvana (mesuryak), at the beginning of their existence on Bali Sadhar, were once done, but it is no longer being done nowadays. In addition, the cutting ceremony as a sign of maturity for a person (mepandes), although still being carried out, starts to be rarely done in the Bali Sadhar community. For the Hindu community in Bali Sadhar, carrying out the redefinition and reconstruction in each of these ceremonies is better understood as one of the Hindu teachings related to the necessity to balance in life. That is, the philosophy is not only understood in the context of religious teachings, but the most important for the community is to apply it in life. The philosophy of balance is not only a means of social behaviour among fellow Balinese but also in relation to the surrounding non-Balinese ethnicity. Not only is it applied in

\footnotetext{
${ }^{10}$ Most of the food ingredients at the Bali Sadhar mengibung ceremony are pork which Muslim community around Bali Sadhar considers illegal. For every ceremony is always related to food, it then brings up an image to the Muslim community around Bali Sadhar that they should not come into contact with any activity carried out by the Bali Sadhar community. This image initially isolated the Bali Sadhar community in its interaction with the community around the most part of the muslim so that since then this mengibung ceremony began rarely to be done.
} 
relations between humans but also in relation to the surrounding environment. To the Bali Sadhar community, the awareness to practice this philosophy is what makes them continue to exist and harmony in the Banjit area without giving rise to divisions, conflicts, and other things that have a negative impact on them.

\section{Conclusion}

The process of redefinition and reconstruction of cultural values in the Bali Sadhar community is not only carried out in the context of the ceremony but also in other aspects of life. The redefinition and reconstruction process is nothing new in the Balinese community. The pura (Hindus temple), for example, as the main place in carrying out Hindu teachings, is actually the result of simplification of various sects that once existed in Bali (Arjawa, 2014). According to Arjawa, this simplification process has been carried out since the 11th century when a Balinese Hindu religious leader at that time (Mpu Kuturan) saw the potential for division and conflict between Hindus in Bali. In the end, pura, which was originally based on sects, was then simplified into just two, namely family pura and communal (shared) pura. This simplification process is not considered something wrong, because simplifying cultural values for the purpose of maintaining balance is the most important thing in the Hindu teachings. This shows that the process of redefinition and reconstruction of cultural values carried out by the Balinese community is already contained in their cultural values.

The case of the Bali Sadhar community shows that the redefinition and reconstruction process was raised and carried out when facing different conditions that forced this community to make conformity. This adjustment process not only enables them to maintain their existence in the migrant area but also is able to show their Balinese identity. This adjustment process is not only able to deal with open conflicts with the surrounding communities but is also able to collaborate politically and economically amid diverse ethnicities and differences. The success of the Bali Sadhar community is more due to the values that they have contained the cultural values to make the process of adjustment (cultural conformity), the philosophy of always maintaining a balance in life. These cultural values are then used by the reservoir plasticity in dealing with various problems in their environment.

This shows that every ethnic group always wants to show and maintain its cultural identity because that identity has been embedded as part of its cultural values. This Bali Sadhar case also shows how ethnic identity politics conducted by each community is able to create a pattern of harmony. This is different from some cases in other areas in Lampung province, where cultural diversity actually creates conflict and arguments (Karomani, 2011; Romli, 2014; Utami, 2014). The multiculturalism of the Banjit community actually shows that the resulting diversity is not in the form of a unification of cultural differences in the society, but rather shows the equality between ethnic groups where each group respects each other. This can happen because each ethnic group has the conformity values (cultural conformity) to always be in harmony and respect for each other.

The case of the Banjit community also shows the fact the concept of multiculturalism also contains values in which each group actually has its own local wisdom in placing and respecting the culture of other groups (Ganap, 2012). This pattern of always respecting each other will always be found in every community culture because they will always be confronted with the 
dualism between conflict and harmony (Needham, 1980). On the one hand, a conflict is possible, because every community always strives to show and maintain its cultural identity, always trying to show its differences and inequality with other groups. But on the other hand, each group also always strives to create harmony with mutual respect and complementarity.

\section{References}

Abdillah, Ubed. 2014. Politik Identitas. Pergulatan Tanda Tanpa Identitas. Jakarta : YOI Afero, Deni \& Hartoyo. 2013. Keharmonisan Hubungan Antar Etnis Bali dengan Etnis Lampung (Studi di Lampung Selatan), dalam Jurnal Sociologie Vol1, No.1. Bandar Lampung : Universitas Lampung

Archer, M.S. 1985. "The Myth of Cultural Integration" dalam The British Journal of Sociology, Vol. 36, No. 3. (Sept., 1985) (pp.333-353).

Archer, M.S. 1982. "Morphogenesis versus Structuration. On Combining Structure and Action" dalam The British Journal of Sociology, Vol. 33, No. 4. (Dec., 1982) (pp.455-483). Arifin, Zainal. 2018a. Politik Perkawinan. Dualitas Praktik Sosial Masyarakat Minangkabau. Yogyakarta : Histokultura Graha Ilmu.

Arifin, Zainal. 2018b. Tunggu Tubang. Pola Kekuasaan dan Penguasaan Sumberdaya di Komunitas Semende Sumatera Selatan. Padang : CV Rumah Kayu Pustaka Utama.

Arifin, Zainal. 2017. Nagari Ba-Ampek Suku. Politicisation Mythical Origins of Minangkabau, dalam Jurnal The Eastern Anthropologist Vol.70 No.1-2. Lucknow (India) : Lucknow University (pp.177-189).

Arifin, Zainal. 2013. Bundo Kanduang (hanya) Pemimpin di Rumah (gadang), dalam Jurnal Antropologi Indonesia Vol.36 No.2. Jakarta : Universitas Indonesia (pp.124-133).

Arifin, Zainal. 2012. Buru Babi : Politik Identias Laki-Laki Minangkabau, dalam Jurnal Humaniora Vol.24 No.1. Yogyakarta : Universitas Gadjah Mada (pp.29- 36).

Arjawa, GPB Suka. 2014. Identitas Kepemilikan Pura dalam Hubungannya dengan Perkembangan Pariwisata dan Konflik Sosial di Bali, dalam Jurnal Masyarakat, Kebudayaan dan Politik Vol.27 No.3. Surabaya : Universitas Airlangga (pp.137-148)

BPS. 2011. Kewarganegaraan, Suku Bangsa, Agama, dan Bahasa Sehari-Hari Penduduk Indonesia. Hasil Sensus Penduduk 2010. Jakarta : BPS.

BPS. 2017. Kecamatan Banjit dalam Angka. Blambangan Umpu : BPS Kabupaten Way Kanan.

Fairusy, Muhajir Al. Model Konsensus Dan Rekonsiliasi Konflik Antar-Umat Beragama Di Aceh Singkil, dalam Jurnal Al-Ijtima'i Vol 1, No 1. Banda Aceh : UIN Ar-raniry

Ganap, Victor. 2012. "Konsep Multikultural dan Etnisitas Pribumi dalam Penelitian Seni” dalam Jurnal Humaniora, FIB UGM (pp.156-167).

Haboddin, Muhtar. 2012. Menguatnya Politik Identitas di Ranah Lokal, dalam Jurnal Studi Pemerintahan Vol.3 No.1. Yogyakarta : Universitas Muhammadiyah Yogyakarta (pp.116134).

Hadikusuma. 1989. Masyarakat dan Adat Budaya Lampung. Bandung : Mandar Maju.

Haryanto, Joko Tri. 2012. Interaksi dan Harmoni Umat Beragama, dalam Jurnal Walisongo Vol.20, No.1. Semarang : UIN Walisongo 
Hefner, Robert W. 2007. Politik Multikultural. Yogyakarta: Penerbit Kanisius. Hintjens, Helen M. 2001. "When Identity Becomes a Knife : Reflecting Genocide in

Rwanda, dalam Journal Ethnicites Vol.1 No.1 (pp.25-55).

Howe, Leo. 2005. The Changing World of Bali. Religion, Society and Tourism.

London and New York : Routledge.

Karomani. 2011. "Persepsi Dan Prasangka Antaretnik Di Lampung Selatan: Studi Komunikasi Antaretnik Di Bakauheni Kalianda" dalam Jurnal Sosiohumaniora Vol.13, No.1. Bandung: Universitas Padjadjaran (pp.39- 40).

Kukathas, Chandran (eds). 1993. Multicultural Citizens. The Philosophy and Politics of Identity. Sydney. The Centre for Independent Studies.

May, Stephen. 1999. "Critical Multiculturalism and Cultural Difference: Avoiding Essentialism” dalam Stephen May (eds). Critical Multiculturalism: Rethinking Multicultural and Antiracist Education. London: UK Falmer Press (pp.12-45).

Miller, David. 1995. On Nationality. Oxford: Oxford University Press.

Mudana, I Wayan. 2012. Modal Sosial dalam Pengintegrasian Etnis Tionghoa Pada Masyarakat Desa Pakraman di Bali, dalam Jurnal Ilmu Sosial dan Humaniora Vol.1, No.1. (pp.30-40). Singaraja : Universitas Pendidikan Ganesha

Needham, R. 1980. "Principles and Variations in the Structure of Sumbanese Society" dalam The Flow of Life: Essays on Eastern Indonesia (eds: J.Fox). Cambridge, Massachusetts: Harvard University Press.

Nicholson, Linda. 2008. Identity Before Identity Politics. Cambridge: Cambridge University Press.

O'Neill, Shane. 2003. "Justice in Ethnically Diverse Societies : A Critique of Political Alienation", dalam Journal Ethnicities Vol.3 No.3 (pp.369-392).

Parekh, B. 2001. Rethinking Multiculturalism: Cultural Diversity and Political Theory. Cambridge, Mass.: Harvard University Press.

Romli, Khomsahrial dan Ayu Maulia. 2014. "Prasangka Sosial Dalam Komunikasi Antaretnis (Studi Antara Suku Bali dengan Suku Lampung di Kecamatan Sidomulyo Kabupaten Lampung Selatan Provinsi Lampung)" dalam Jurnal Kom \& Realitas Sosial Vol.4, No.2. Bandar Lampung: Universitas Bandar Lampung (pp.127-151).

Setyaningrum, Arie. 2003. Multikulturalisme Sebagai Identitas Kolektif, Kebijakan Politik dan Realitas Sosial. dalam Jurnal Ilmu Sosial dan Ilmu Politik Vol.7 No.2. Yogyakarta : Universitas Gadjah Mada (pp.243-260).

Sjaf, Sofyan. 2014. Politik Etnik, Dinamika Politik Lokal di Kendari. Jakarta : YOI Spradley, J.P dan D.W. McCurdy. 1987. Conformity and Conflict. Reading in

Cultural Anthropology (6th edition). Boston Toronto: Little, Brown and Company.

Suparlan, Parsudi. 2002. Menuju Masyarakat Indonesia yang Multikultural, dalam Jurnal Antropologi Indonesia Vol.69 No.3. Jakarta : Universitas Indonesia (pp.98-105).

Syaifuddin, Achmad Fedyani. 2006. "Membumikan Multikulturalisme di Indonesia" dalam Jurnal Etnovisi Vol.II, No.1 (April 2006). Departemen Antropologi, FISIP USU (pp.3-11). Tanudirjo, Daud Aris. 2011. "Membangun Pemahaman Multikulturalisme: Perspektif Arkeologi" disampaika dalam Workshop "Multikulturalisme dan Integrasi Bangsa dalam Pembangunan Kebudayaan dan Pariwisata" di Kusuma Sahid Prince Hotel, Solo tanggal 5 Mei 2011. 
Tarakanita, Irene \& Maria Yuni Megarini Cahyono. 2013. Komitmen Identitas Etnik dalam Kaitannya dengan Eksistensi Budaya Lokal. dalam Jurnal Zenit Vol.2 No.2. Bandung : Universitas Kristen Maranatha (pp.98-105).

Utami, Anisa. 2014. Resolusi Konflik Antar Etnis di Kabupaten Lampung Selatan (Studi Kasus: Konflik Suku Bali Desa Balinuraga Dan Suku Lampung Desa Agom Kabupaten Lampung Selatan), dalam Journal Of Politic And Government Studies Vol.3 No.2. Semarang : Universitas Diponogoro (pp.1-23).

Wasino. 2013. "Indonesia: From Pluralism to Multiculturalism" dalam Jurnal Paramita Vol.23, No.2 (Juli, 2013). Jurusan Sejarah, FIS Universitas Negeri Semarang (pp.148-155).

West-Newman, Catherine Lane. 2004. "Anger, Ethnicity, and Claiming Identity”, dalam journal Ethnicities Vol.4 No.1 (pp.27-52).

Yanti, Ketut Leni \& Ali Imron \& Suparman Arif. 2014. Perkawinan Beda Kasta pada Masyarakat Balinuraga di Lampung Selatan, dalam Jurnal Pendidikan dan Penelitian Sejarah Vol.2, No.2. Bandar Lampung :Universitas Lampung.

Zulfa, Eva Achjani. 2014. Bali Nuraga Lampung: Identity Conflict Behind The Policy" dalam Indonesian Journal of International Law Vol 11, No 2. Jakarta : Fakultas Hukum Universitas Indonesia (pp.261-283). 